\title{
Analisis dan Perancangan Website Desa Kare Dengan Menggunakan Content Management
}

\author{
Muh Nur Luthfi Azis ${ }^{1}$, Yoga Prisma Yuda ${ }^{2}$, Sri Anardani ${ }^{3}$ \\ ${ }^{1}$ Program Studi Informatika, Universitas PGRI Madiun, Jl Auri No.14-16, Kota Madiun, 63117 \\ E-mail: nur.azis@unipma.ac.id \\ ${ }^{2}$ Program Studi Informatika, Universitas PGRI Madiun, Jl Auri No.14-16, Kota Madiun, 63117 \\ E-mail:nur.azis@unipma.ac.id \\ ${ }^{3}$ Program Studi Informatika, Universitas PGRI Madiun, Jl Auri No.14-16, Kota Madiun, 63117 \\ E-mail: nur.azis@unipma.ac.id
}

\begin{abstract}
Digitalization is an era in which we as humans are expected to be able to follow the development of technology that is developing very rapidly today, where at this time almost all promotional or business information in many forms uses existing technology using the Internet network, almost everything with the internet makes work become easy to convey information ranging from the latest news and information even the longest can be accessed at any time because everything is stored in the database of a website. Kare Village is a village located far from urban areas in Madiun, East Java, where it takes a very long time to reach the village, but the village has many advantages including tourism potential that has not been explored and developed due to the lack of promotional media. From this, the writer wants to do research on a website design that introduces the village and introduces the tourism potential in the area which is expected to increase the income of the village.
\end{abstract}

Keywords—: Analysis; Design; Website; Information System; CMS.

\section{PENDAHULUAN}

Digitalisasi merupakan era dimana kita sebagai manusia di harapkan bisa mengikuti perkembangan teknologi yang berkembang sangatlah pesat saat ini, dimana zaman ini semua hampir semua informasi promosi atau bisnis dalam banyak bentuk menggunakan teknologi yang ada dengan menggunakan jaringan Internet, hampir semuanya dengan internet menjadikan pekerjaan menjadi mudah menyampaikan informasi mulai dari berita terbaru maupun informasi-informasi yang paling lama sekalipun bisa di akses setiap waktunya karena semua di simpan di dalam database sebuah Website.

Dimana E-Government menjadi suatu sistem informasi yang sangat banyak digunakan sekarang ini sejalan dengan perkembangan teknologi informasi dan komunikasi. Begitu juga dengan desa Tresnomaju yang perlu mengimplementasikan $E$ Government dengan strategi yang disesuaikan dengan kondisi sosial yang tujuan akhirnya diharapkan meningkatkan kualitas kinerja perangkat desa terutama dalam lingkup pelayanan masyarakat sehingga dapat bermanfaat bagi segenap masyarakatnya untuk mengetahui informasi informasi yang ada. Menyadari akan besarnya manfaat e-government, pemerintah indonesia sejak tahun 2003 telah mengeluarkan kebijakan tentang penerapan e-government dalam bentuk instruksi presiden nomor 3 tahun 2003. (Dalam Jurnal Aplikasi E-government Pada Desa Jatirejo,tahun 2013 oleh Fitria)

Dari hal tersebut peneliti mengambil tema penelitian "Analisis dan Perancangan Website Desa Kare dengan menggunakan Content Management system" dimana Desa kare merupakan desa yang terletak di timur kurang lebih perjalanan memerlukan waktu kurang lebih 40 menit dari kota madiun, desa kare mengalami beberapa hambatan terutama dalam empromosikan desanya, setelah di lakukan penelitian ternyata desa kare sudah terjangkau internet dan desa tersebut memerlukan promosi kaitannya dengan wisata dan pengenalan desa kare.

\section{A. Tujuan Penelitian}

Berdasarkan dari apa yang di dapatkan dari rumusan masalah dapat di ambil pemahaman untuk di jadikan tujuan sebagai berikut:

1. Menghasilkan perancangan website desa kare yang baik, dan bisa di terapkan secara maksimal di kemudian hari

2. Membantu mewujudkan pemecahan permasalahan yang di alami desa kare untuk saat ini, dimana desa kare merupakan desa yang perlu pengenalan kepada publik terkait dengan destinasi wisata ataupun keberadaan desa kare

3. Berusaha memberikan gambaran kemudahan akses warga ketika menggunakan teknologi maupun pengenalan desa kepada publik 
Manfaat yang diperoleh dari hasil penelitian ini dapat dijelaskan sebagai berikut:

1. Diharapkan bisa menjadikan referensi pihak desa untuk mengimplementasikan pembangunan website desa sebagai media promosi dan sebagai pengenalan keberadaan desa yang mempunyai banyak potensi yang baik

2. Diharapkan ketika perancangan nanti akan di bangun yaitu bisa mempermudah komunikasi masyarakat desa kare dengan pemerintah desa jika suatu saat ada pemberitahuan dan lain sebagainya

3. Diharapkan dengan adanya perancangan ini kedepan masyarakat tidak perlu datang ke desa untuk mendapatkan pelayanan

\section{Luaran Penelitian}

Penelitian ini memiliki luaran yang harus dicapai, sehingga kualitas penelitian ini dapat diandalkan. Luaran penelitian ini adalah:

1. Laporan akhir penelitian

2. Publikasi di jurnal nasional

3. Aplikasi Moodle untuk Rekayasa Perangkat Lunak dan Pemrograman Web

\section{METODE PENELITIAN}

\section{A. Desain Penelitian}

Penelitian ini menggunakan pendekatan penelitian Observasi wawancara dan Dokumentasi, dimana penulis melakukan wawancara kepada pihak yang akan bersangkutan dengan Website yang akan di bangun nantinya yaitu meliputi kepala desa dan staff dan di lanjutkand dengan melakukan dokumentasi yaitu dengan mengambil sample berkas yang akan di pakai sebagai acuan pembangunan vitur website.

\section{B. Tempat dan Waktu Penelitian}

Rencana kegiatan penelitian ini dilakukan di tempat dan obyek penelitian, yaitu

1. Tempat dan ojek penelitian : Pemerintah Desa Kare

2. Waktu Penelitian : 3 bulan (Juni, Juli. Agustus) Tahun 2019

\section{Rancangan Penelitian dan Teknik Analisis Data}

Dibawah ini merupakan gambaran yang akan di lakukan peneliti pada penelitian kali ini

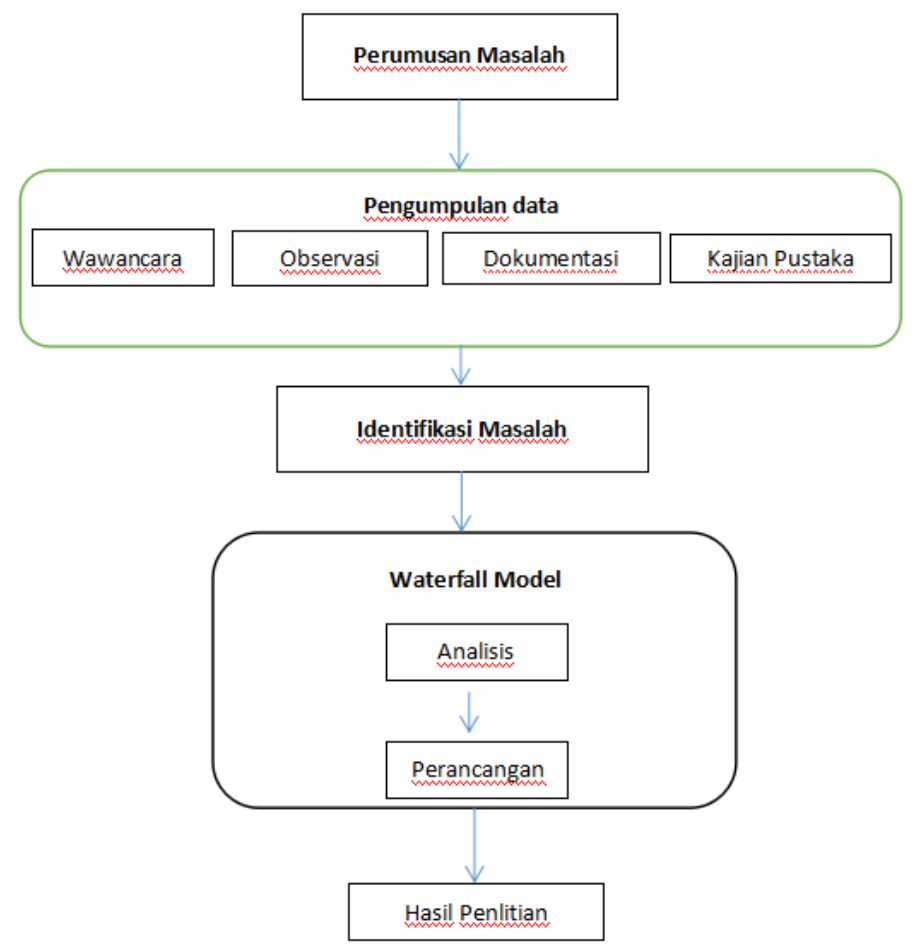

Gambar 1. Metode Penelitian

Penelitian akan di laksanakan pada desa kare kec. Kare, kabupaten madiun jawa timur, dimana metode penlitian yang akan di pakai sebagai berikut. 


\section{Interview}

Dalam tahapan ini penelti melakukan tanya jawab secara langsung untuk mendengarkan fitur apa yang kira-kira di butuhkan oleh pemerintah desa kare yang meliputi kepala desa, staf dan jajarannya, dari hal tersebut di dapatkan kesimpulan bahwasannya pemerintah ingin memperkenalkan desa kare kepada publik atau masyarakat luas dan di harapkan kerangka atau perancangan yang akan di buat nanti bisa memberikan solusi untuk bisa mempromosikan desa kare

\section{Observasi}

Dalam tahapan ini peneliti melakukan pencarian referensi desa yang sudah melakukan pembangunan website desa dan bisa berjalan dengan baik dengan mengkombinasikan desa tersebut dan mencari kelemahan dari masing-masing website dan dari kelemahan tersebut nanti bisa menjadikan optimalisasi untuk peningkatan perancangan website desa kare

\section{Dokumentasi}

Dalam tahapan ini peneliti melakukan pengambilan data yang nantinya bisa untuk menunjang optimalisasi pembangunan perancangan sistem di antaranya adalah daftar kepala desa beserta staf daftar kampung yang ada di wilayah desa kare dan potensi wisata yang ada di desa kare.

\section{III.HASIL DAN PEMBAHASAN}

\section{A. Gambaran Umum Lokasi Penelitian}

Legenda Desa ini diambil dari penuturan para orang tua / dongeng dari satuorang ke orang lain yang sudah turun temurun di Desa Kare; dongeng atau kisahnya sebagai berikut : Di lereng Gunung Wilis hidup seorang tokoh bernama Ki Ageng Wilis sesuai dengan tempat pertapaannya. Ki Ageng Wilis mempunyai keponakan yang bernama Ki Joko Slining. Pada suatu hari, Ki Joko Slining akan mempersunting seorang putri bernama Putri Kencono Wungu yang merupakan keponakan dari Adipati Madiun yang disayembarakan untuk mencari jodoh. Mendengar berita itu, maka pada siang hari berangkat Ki Joko Slining dengan sahabatnya menuju Padepokan Putri Kencono Wungu dengan menaiki sebuah perahu sampan dari batu mulai dari puncak Gunung Wilis.

Di tengah perjalanan perahu tersebut terjebak oleh pusaran air. Untuk mengenang tempat tersebut maka diberi nama Seran. Setelah berhasil melewati pusaran air, perjalanan dilanjutkan. Tapi karena teman Joko Slinning kelelahan, maka ia tertidur lama (suwe turu wae = bhs. Jawa ). Di suatu tempat di atas batu yang bernama Selo Bekel maka untuk mengingat tempat tersebut diberi nama Suweru. Setelah temannya bangun dari tidur, perjalanan dilanjutkan. Namun karena kecapekan dan baru bangun dari tidur maka kapal yang ditumpangi terpleset tapi masih selamat. Maka tempat terpleset itu diberi nama Plosorejo. Kemudian setelah berjalan beberapa saat, hari sudah menjelang sore dan tiba di suatu tempat melihat ada bunga Dipoyono yang sangat indah,maka bunga itu dipetik untuk tanda melamar Putri Kencono Wungu. Untuk mengenang tempat pemetikan bunga tersebut, maka daerah itu diberi nama Kare ( berasal dari kata Sekar Mekar Sore ). Setelah dilanjutkan perjalanan, tali kapal yang ditali wangsul berkali-kali putus.

Oleh karena itu, tempat itu diberi nma Gondosuli ( Gonta ganti tali Wangsul ). Tali yang terputus tadi disambung-sambung di suatu tempat yang kemudian dinamai Sambong. Dalam perjalanannya ternyata perahu yang ditumpangi tersangkut di suatu tempat sampai pagi tiba, sehingga Ki Joko Slining tak bisa mengikuti sayembara. Ia merasa gagal dan malu karena tak bisa mengikuti sayembara mempersunting Putri Kencono Wungu. Maka tempat itu dinamai Kuwiran ( kewirangan = Bhs. Jawa ) sehingga kapalnya ditinggal begitu saja di sana. Kapal tersebut sampai sekarang masih ada di tengah hutan di Desa Kuwiran. Ini lah legenda Desa Kare agar anak cucu warga Desa Kare mengetahui asal usul nama desanya.

Asal Usul Penduduk Desa KareAsal usul penduduk Desa Kare menurut penuturan / dongeng orang tua secara turun temurun yaitu :Pada zaman dahulu datang serombongan petani dari daerah Caruban. Mereka hidup sebagai petani yang meninggalkan daerah asalnya karena ingin aman dari kekejaman bangsa Belanda. Rombongan ini dipimpin seorang bernama KARTODIPURO. Dengan hidup bertani secara tekun dan membawa pengalaman dari daerah asal maka hasil tani sangat memuaskan.Banyak petani yamg berbondong-bondong menuju daerah pak Kartodipuro. Namun sayangnya daerah yang ditempati pak Kartodipuro masih menjadi satu dengan Desa SALAK, yang sekarang menjadi dukuh Salak termasuk Desa Randualas. Berhubung makin banyak pengikut menuju daerah pak Kartodipuro maka diadakan pemekaran Desa Salak. Dengan demikian daerah yang ditempati pak Karto merupakan daerah baru " Mekare Desa Salak “. Kata Mekare kemudian dikenal dengan Desa KARE. Daerah Kare merupakan daerah yang merupakan pelarian dari orang-orang yang tidak mau tunduk kepada Belanda. Selanjutnya, Desa Kare makin ramai dan didirikan pemerintahan tingkat Kawedanan yang bertempat di Dusun Kare. Pemangku Wedono pada saat itu bernama KARTO HADIKUSUMO. Namun akhirnya pusat Kawedanan dipindahkan ke Kanigoro.

Dari sejarah yang sangat detail di atas pemerintah desa kare ingin lebih memperkenalkan desanya ke publik yaitu berkaitan dengan Poternsi Wisata dan keunggulan-keunggulan yang di miliki desa kare lainnya

\section{B. DAD yang berjalan Saat ini}


DAD dibawah ini merupakan sistem yang sedang berjalan di desa kare saat dalam hal pelaayanan masyarakat, dimana proses ini membutuhkan waktu yang agak panjang dalam prosesnya karena harus mengumpulkan pertanyaan-pertanyaan terlebih dahulu secara manual ke desa melaku aparat pemerintah yang ada di masing-masing kampung

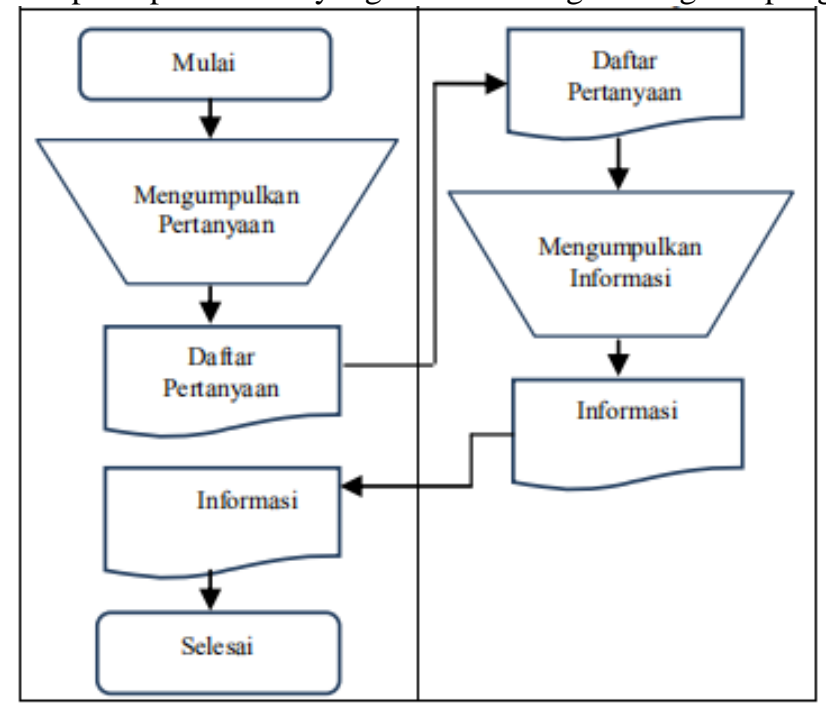

Gambar 2. DAD yang Berjalan Saat Ini

\section{DAD yang di inginkan}

Di bawah ini merupakan sistem yang akan di bangun berupa perancangan website Desa kare kabupaten madiun jika kita lihat dalam perancangan website ini nanti akan memberikan kemudahan dimana semua masyarakat baik desa kare ataupun di luar desa kare yang ingin mencari informasi desa kare dapat mengakses secara online

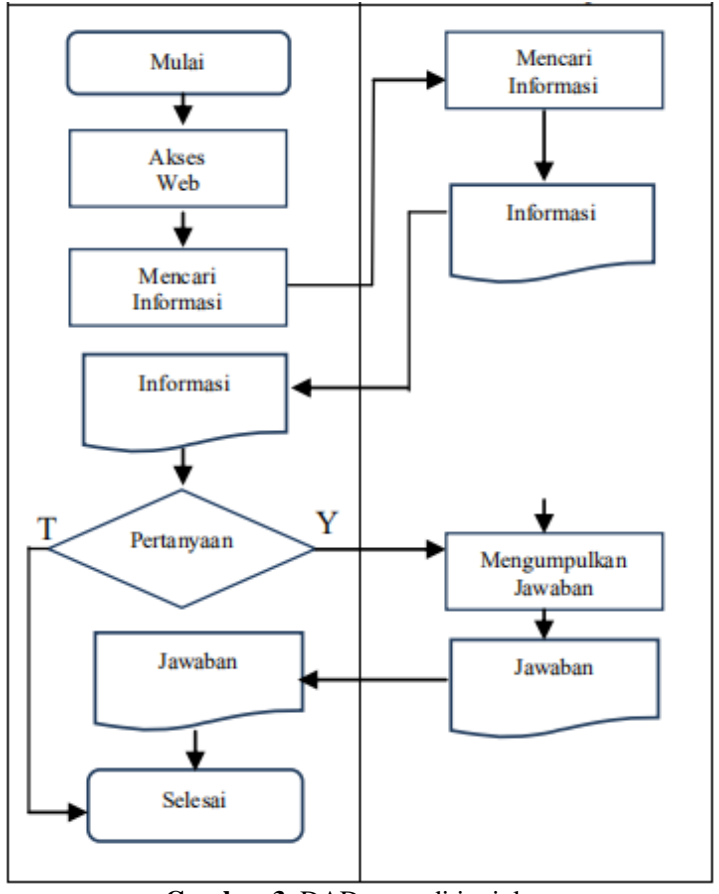

Gambar 3. DAD yang di inginkan

\section{Diagram Konteks}

Diagram konteks merupakan diagram yang terdiri dari suatu proses dan menggambarkan ruang lingkup suatu sistem, dimana jika kita lihat di bawah ini ada 3 entitas yaitu Admin, Kepala Desa, masyarakat, dimana admin adalah sebagai pengendali utamanya atau biasa di sebut superadmin, admin bisa melakukan apa saja yang ada di dalam webiste termasuk mengatur role 
hak akses, sedangkan kepala desa hanya bisa melihat dan mengatur sedikit apa yang ada di sistem hanya sebagai kontrol utama dalam pemerintahan akan tetapi kepala desa bisa publish informasi yang sifatnya tidak bisa di wakilkan kepada admin atau informasi yang perlu di sampaikan kepada masyarakat secara cepat, dan jika kita melihat entitas dari masyarakat hanya mendapatkan informasi dari website tersebut, untuk mendapatkan informasi lebih masyarakat harus meninggalkan pesan di kolom pesan yang sudah di sediakan dalam website

Bagan diagram Konteks

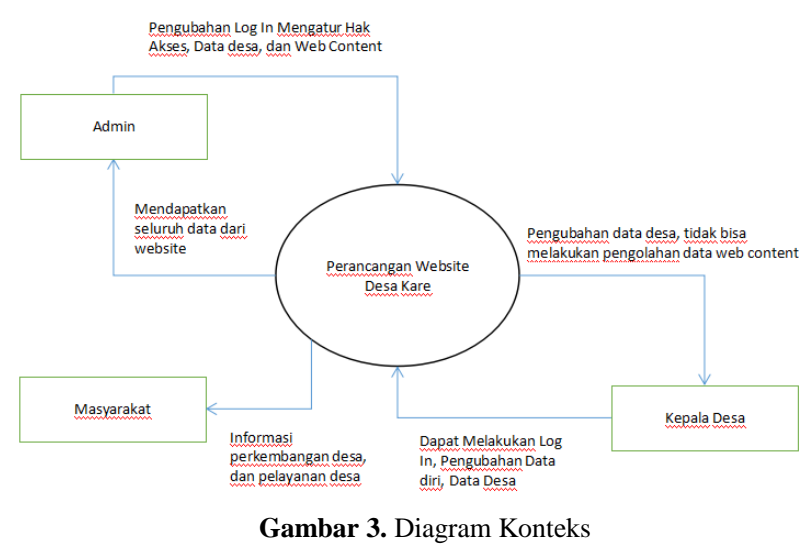

\section{E. Rancangan Website desa Kare}

Dalam perencanaan pembangunan website desa kare peneliti membuat desain sebagai gambaran pemerintah desa dan di harapkan gambar desain yang di buat nantinya bisa memberikan manfaat dan pencerahan untuk nantinya bisa di terapkan di dalam pembuatan website desa kare

\section{F. Desain Antar Muka}

\section{Tampilan Log in}

Pada antarmuka ini di karenakan menggunakan content management system dalam pembangunannya untuk halaman utama $\log$ in peneliti memberikan gambaran default dari content management system yang ada, akan tetapi jika ingin merubah tampilan default masih tetap bisa di lakukan

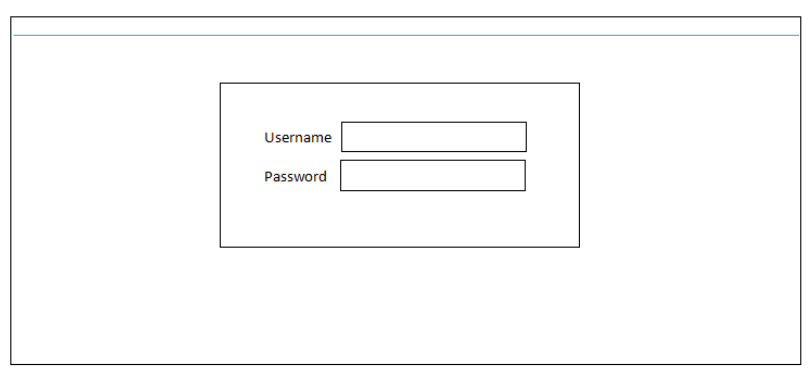

Gambar 3. Halaman log In

Tampilan Halaman utama Admin

Pada tahapan ini peneliti bisa membangun costum sesuai dengan request dari pemerintah desa kare, dimana jika ingin di tambahkan fitur2 lain tetap bisa di lakukan meskipun ada tampilan content manajement system yang default 


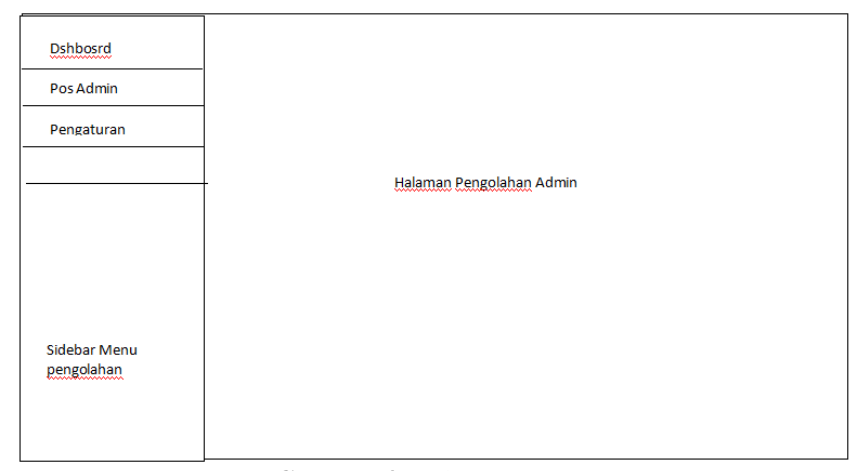

Gambar 4. Halaman Master

Tampilan antar muka Home

Di bawah merupakan tampilan home dari perancangan website desa kare dimana pada desain tampilan antar muka Home ini di tujukan untuk masyarakat yang ingin melihat informasi ataupun yang ingin mengenal desa kare dan potensi wisata desa lebih mendalam, dimana di dalamnya ada header,laman, content, dan footer, untuk header sendiri nantinya bisa di gunakan untuk iklan advertising UMKM desa kare atau potensi wisata desa kare, untuk bagian laman nantinya akan menampilkan menu dan sub menu diantaranya HOME, Profil Desa, Struktur Pemerintah desa Kare Potensi Wisata dan informasi masyarakat serta contact person Pemerintah desa

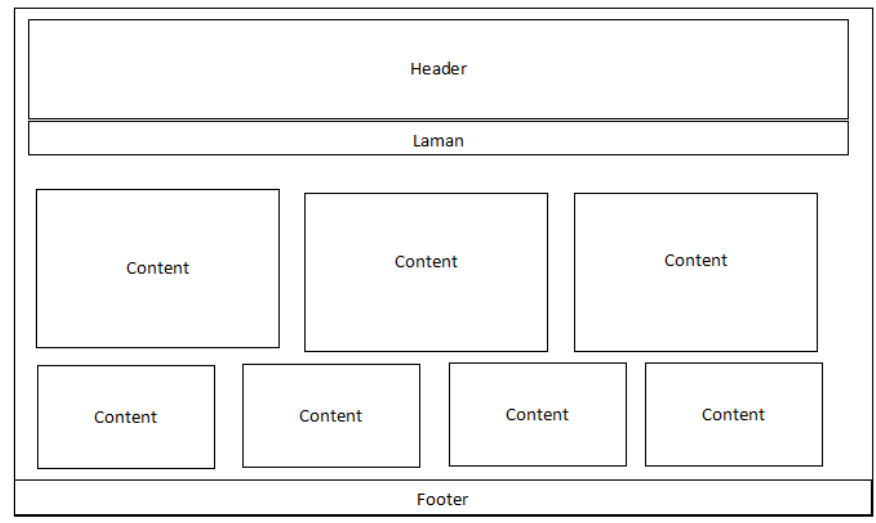

Gambar 5. Halaman user

\section{IV.DAFTAR PUSTAKA}

Agustina, Lia. 2013. Jurnal sistem e-government pada pekon tangkit serdang kecamatan pugung kab. Tanggamus program S-1 STMIK Pringsewu.

Dewi Retnowati, Nurcahyani. 2008. Jurnal Peranan E-government Dalam Mewujudkan Good Governance Bagi Masyarakat Sekolah Tinggi Teknologi Adisutjipto Yogyakarta.

Abdul Kadir \& Terra Ch. Triwahyuni, Pengenalan Teknologi Informasi,Andi Offset. Yogyakarta, 2003

Anhar, Panduan Menguasai PHP \& MySQL Secara Otodidak, Media Kita, Jakarta,2010

Davis, B. Gordon.and H. Olson,Margrethe, Management Information System: Conceptual Foundations, Structure, and Development, Second Edition, McGrawHill: Series in Management Information System; McGraw- Hill, Inc.; USA, 1985

Fathansyah, 2007. "Buku Teks Komputer Basis Data”. Fitria. 2013. Jurnal Aplikasi E-government Pada Desa Jatirejo.

IJNS - Indonesian Journal on Networking and Security - Volume 3 No 3 Juli - 2014 - http://ijns.org, ISSN: 2302-5700 (Print) 2354-6654 (Online), Pembuatan Website Portal Berita Desa Jetis Lor, Bhirawa Anoraga Nandari, Sukadi jaimputramandala@ gmail.com

Hartono, Dwiarso Utomo, dkk., Electronik Government Pemberdayaan Pemerintahan dan Potensi Desa Berbasis Web, vol. 6 no. 1 , Sragen, April 2010

Henny Hendarti, Nurlina. Jurnal Perancangan aplikisi pembuatan kartu tanda penduduk berbasis web dapa kodya bekasi, 2008. 